\title{
Link between Corporate Philanthropy and Corporate Financial Performance: Evidence from Pakistani Textile Sector
}

\author{
S. ZULFIQAR \\ University of Debrecen
}

\begin{abstract}
Literature highlights the immense potential of Corporate Philanthropy (CP) for generating social and economic benefits. The debate on economic benefits align corporate philanthropy with the business bottom line arguing that it can be a significant determinant of corporate financial performance. This research is intended to extent this debate by providing sector specific perspective through analyzing the sample of Pakistani public listed textile companies. Results of the study show that corporate philanthropy has a significantly positive relationship with Return on Assets (ROA) but with Return on Equity (ROE) the relationship is found to be insignificant. The previous year's financial performance moderates the relationship between CP and ROA but the interaction effect for ROE is insignificant.
\end{abstract}

\section{Introduction}

Modern history of corporate philanthropy started when there was a law case filed in New Jersey Supreme Court in 1953. The decision of the court made it possible for A. P. Smith Manufacturing Company to made donation of $\$ 1500$ to Princeton University without the violation of shareholders interest. After its inception, for decades the corporate philanthropy was stigmatized if leading to any corporate gains; this altruistic view hold the notion that the companies should invest in communities irrespective of any financial returns. [6] But the economists holding pure capitalist opinion criticize the altruistic view on corporate philanthropy suggesting that companies should only invest in those activities that maximize the shareholder's wealth. However more recently the term strategic philanthropy has become popular leading to compromise between the altruistic and capitalist views and suggest that companies should make social investments but these investments need to be tied with the strategic goals of the organization. [9] In fact such investments can optimize the social and economic benefits and create win-win situation for both business and society. The literature on the economic benefits show that corporate philanthropy is a two way road if strategically handled, it can positively influence firm's competitive advantage, moral reputational capital and financial performance. [13] [16] [20]

However the studies conducted how Corporate Philanthropy (CP) affect Corporate Financial Performance (CFP) show varied findings from positive, negative, no relationship to inverse U-shaped curvilinear relationship between the two variables. [8] [20] The major reason for the inconsistency in the results of previous studies is large cross sectional datasets in which industry specific effects are usually lost. [18] Different industries pose different demands and outcomes for corporate philanthropy can be varying across industries. Sector specific studies on the link between CP and CFP 
can lead to better understanding of relationship between variables. The current study is intended to address this need by providing sector specific perspective on the relationship between corporate philanthropy and corporate financial performance by analyzing the public listed companies of Textile sector in Pakistan.

\section{Textile sector of Pakistan}

Textile companies are significant component of Pakistan's corporate sector and said to be the backbone of economy. Textile is the largest manufacturing and major employment generating industry in Pakistan. The major export of Pakistan is textile related products making it the eight largest exporters of textile goods in Asia. The contribution of textile towards Pakistan's economy is vital because Pakistan is the fourth largest cotton producing country with third largest spinning capacity in Asia which contributes around 5\% to the worldwide spinning capacity. The value chain of textile sector is divided into sub categories such as spinning, weaving, processing, printing and garment manufacturing.

\section{Literature Review}

\section{Corporate Philanthropy}

Carroll $(1979,1991$ and 1999) presented the most influential paradigm in the domain of Corporate Social Responsibility (CSR) that can be used to define corporate philanthropy. Carroll presented four dimensional definition of CSR in the form of pyramid. [3] The base of the pyramid is economic responsibility where the business has to produce and sell services and products at profit. Legal responsibility of the business is defined as rules of game where the firms have to abide laws and regulations imposed by the government. Ethical responsibilities are those activities that are considered ethical by the society even though they are not imposed by law. The top of the pyramid is discretionary responsibilities that are later replaced by Carroll. [3] As philanthropic responsibilities encompass those activities that are initiated in response to the society's expectation of firm being a corporate citizen.

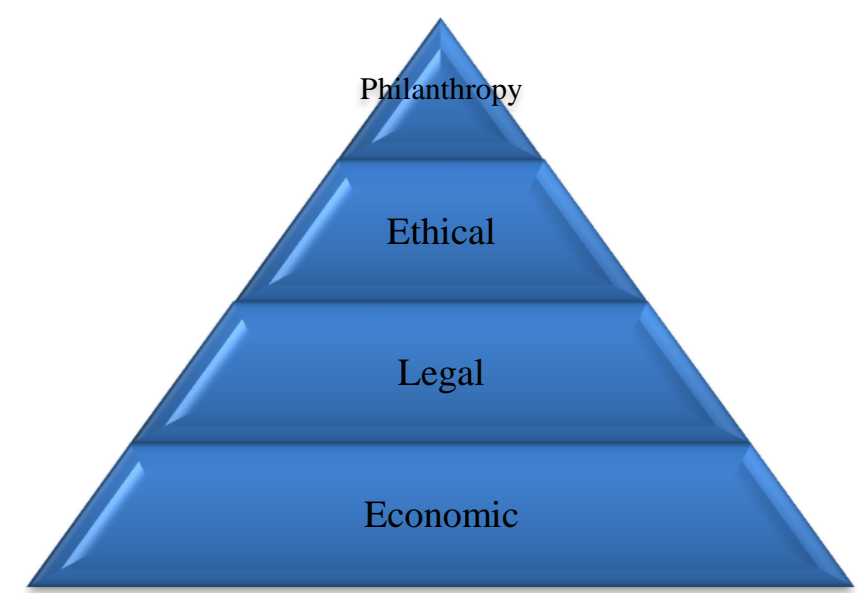

Figure 1: Model of Corporate Social Responsibility

(Source: Carroll, 1991) 
Pervious literature show that corporate philanthropy is not only associated with the social benefits but it also connected with generating economic benefits for the company. This connection can be more precisely explained by the term strategic philanthropy. Strategic philanthropy is defined as a type of corporate giving that serves the dual purpose by donating to charitable causes and at the same time enhancing company's financial performance and political legitimacy. [11] There is a difference between strategic philanthropy and philanthropic strategy. [14] Philanthropic strategy is when the company has formal processes or methods for making donations, whereas strategic philanthropy is when the company create value for both itself and recipient by linking company' mission and goals with philanthropic initiatives. There are four types of strategic philanthropic programs: [12]

1. In-kind giving: non-cash donations in the form of products and services

2. Corporate employee volunteer programs: the employees dedicate time and resources for voluntary reasons to the nongovernmental organizations or other organizations

3. Venture philanthropy: the organization provide monetary and non-monetary support(resources and expertise) to the community based organization for some definite cause

4. Cause related marketing: form of marketing strategy but more than just increasing the sales

\section{Corporate Philanthropy and Corporate Financial Performance}

Corporate philanthropy can be use to converge the social and economic objectives of the organization to improve long-term standing of the business. These objectives are diverse but not conflicting and companies can identify those social causes that are aligned with the business expertise in order to create synergy between its economic and social objectives. [6] Porter and Kramer argued that if the company has strategic orientation about its philanthropic activities it can improve its competitive context. [13] Resource based theory and resource dependence theory can used to explain the link between corporate philanthropy and economic benefits. The strategic philanthropy can increase firm's revenues by facilitating the acquisition of unique and firm specific resources (e.g. brand name and brand reputation) and can ensure the supply of critical resources (e.g. the company make donations in the communities where it has large plant and it can continue getting support from the communities where it operates) thus reducing the cost and increasing the profitability that help firm improve its competitive position and ultimately have positive impact on the financial performance of the company. [17]

Similarly using stakeholder perspective it can be argued that when company denote for social causes it elicits goodwill from different stakeholders including consumers, employees and community. [7] This has special implications for the industries that have noticeable social issues such as tobacco and alcohol. Philanthropic contributions in the awareness programs or rehabilitation programs can have positive impact on the corporate reputation; as stakeholders perceive it as reparation of the harmful aspect of the company's products and services. [2] The managers that value integrity and benevolence and show concern towards society by engaging in philanthropic activities can induce trust and credibility in all stakeholders thereby leading to improved financial performance. [5]

Preston and O'Bannon referred this as social impact of stakeholder theory and argued that if expectations of various stakeholders are not satisfied can cost the organization e.g. increasing risk premium or lost profit opportunities but if these expectations are full filled it can lead to improved corporate reputation and positive financial performance of the company. [15] The relationship 
between CP and CFP might be zero-sum in the short run as the firm has to compromise its profits but it can pay off in the long run in the form of increased employee motivation and social legitimacy. [10]

The staregic philathropy can be used as a marketing tool by the companies which can yield postive finanical and social returns referred as cause related marketing. For example Fox, Faff, Navissi (2011) [8] conducted study on corporate donations by analzing chinese equity market after the Wenchuan earthquake in 2008 and found that the companies that directly donated products and services to the consumer earned higher stock returns. They associated cause of abnormal returns to the marketing effect of corporate donations that lead to incraase brand image and awarness. But it is important to mention that the level of philanthropic contributions is significant. Corporate philanthropy at certain level can help firm secure resources that are critical which will positively influence financial performance but once the corporate philanthropy exceeds the sufficient higher level, the positive effect will be lost because of agency costs, direct costs and unwillingness of the different stakeholders to further compromise their benefits; this will negatively affect financial performance. [21]

Despite this considerable debate in the literature on the economic benefits of corporate philanthropy there is significant variation in the amount of donations made by firms. There is no conclusive evidence on how much the companies should donate that will generate maximum economic benefits. As the decision of how much to donate is relative and vary across firm attributes such as size, profitability, visibility, political connections and most importantly the resources available at its disposal. [1] The philanthropic donations are largely dependent on the financial position of the company. Companies engage in corporate philanthropy only if its financial resources permit that are tied with the previous financial performance.

Waddock and Graves (1997) argued that the link between the financial performance and the corporate social performance is simultaneous which they termed as virtuous cycle i.e. past financial performance of the firm affect the corporate social performance which then effect the future financial performance of the firm. [19] They argued that better financial performance of the firm lead to greater availability of slack resources enabling the firm to invest more in philanthropic programs and increase its social performance which in return enhances its financial performance. [20] So the relationship between CP and current corporate financial performance vary across the different levels of past corporate financial performance such that the positive relationship between corporate philanthropy and current corporate financial performance will be stronger for better pervious corporate financial performance.

- Hypothesis 1: There is a significant positive relationship between corporate philanthropy and corporate financial performance.

- Hypothesis 2: The past financial performance moderates the relationship between corporate philanthropy and current corporate financial performance. 


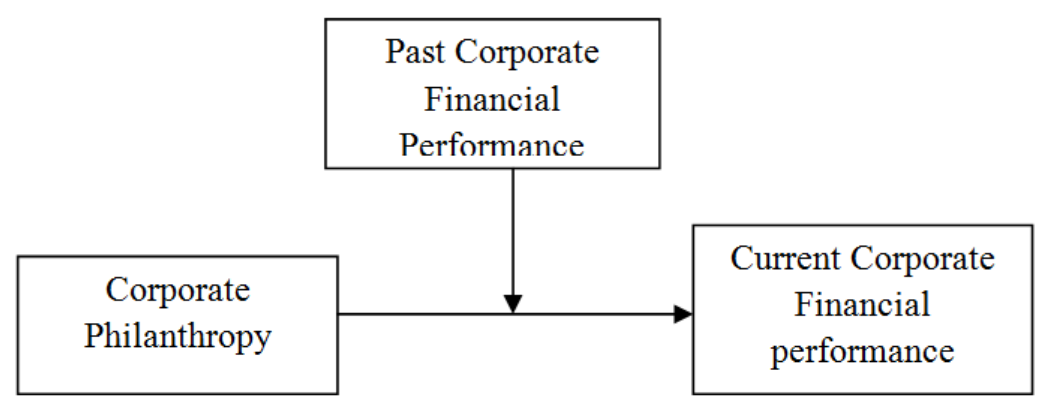

Theoretical Framework

Figure 2

\section{Methodology}

\section{Data and Sample}

The data consisted of textile companies listed at Pakistan stock exchange (PSE) formally three stock exchanges (Karachi, Lahore and Islamabad) merged as one in 2016. There are total 166 textile companies listed at PSE but 80 companies were included in the final analysis. The basic criteria for inclusion of company in the analysis were its engagement in donations and the availability of data for donations for last six years with starting year as 2009 till 2014. The reason for analyzing six years was the availability of data, as the primary source of data was the annual reports available on the official websites of the companies and for majority of companies five years reports were accessible. The other source of data was the financial analysis of non financial-sector conducted yearly by State Bank of Pakistan. The panel type data was used for the analysis. The data for the study was the combination of cross-sectional and longitudinal as all the companies were analyzed for the period of six years from 2006 to 2014.

\section{Measures}

Corporate Philanthropy: The independent variable of the study is corporate philanthropy and for this study only cash donations are considered. It is measured using the amount of annual donations reported in the annual reports of the companies.

Financial Performance: The dependent variable of the study is current corporate financial performance of the companies. It is measured using two financial ratios Return on Assets (ROA) and Return on Equity (ROE). ROA and ROE are two most commonly used ratios to measure firm's financial performance.

Return on Assets (ROA): It is a financial ratio showing the extent to which the company is efficiently managing its assets to generate income. It shows the extent to which the company's assets are profitable in generating income. It is calculated by dividing net income of the company by its total assets:

$$
\text { ROA }=\frac{\text { Net Income }}{\text { Average Total Assets }}
$$


Return on Equity (ROE): ROE is a financial ratio showing how much profit a company generates with the money invested by its shareholders. It shows to the extent company is utilizing its investments to generate earnings growth. ROE is measured dividing net income of the company by shareholder equity.

$$
\mathrm{ROE}=\frac{\text { Net Income }}{\text { Shareholder Equity }}
$$

Past financial performance: Past corporate financial performance is used as a moderator. It is measured by creating a lag term ( $\mathrm{t}-1)$. The ROA and ROE was lagged by one year.

Control Variables: For the current study three control variables are used: company size, company age and debt to equity ratio. Company size can affect its engagement in philanthropic initiatives as larger firms have economics of scale so there are more resources to engage in corporate philanthropy as compare to the smaller firms. Company size is measured using the natural log of the total assets of the company. Company's age can also affect the philanthropic donations; older firms are established and have the internal inertia to engage in philanthropic donations. Company's age was measured by counting the adding up the years since the company was launched. Debt ratio in the capital structure of the company can affect its engagement in philanthropic initiatives as company having more debt can have financial constraints which can restrict the engagement of the company in the corporate philanthropy. Debt to equity ratio was measured by dividing total liabilities of the company by shareholder's equity.

The Econometric Model:

Following econometric equations were used to test the hypothesis:

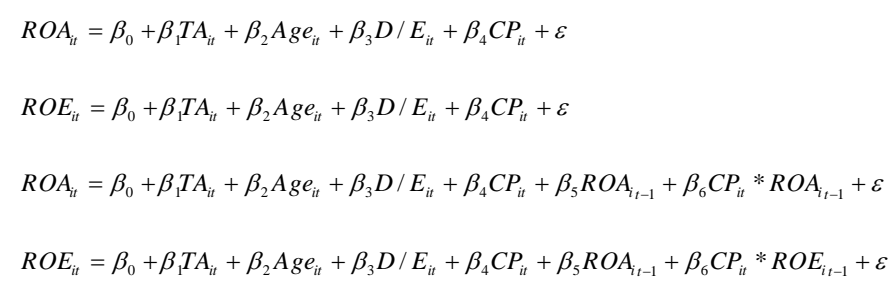

Whereas:

i shows the cross section (Textile companies)

t shows the time series (years)

ROA is Return on Assets and ROE is Return on Equity are the measures of dependent variables i.e. current financial performance. $\mathrm{CP}$ is showing the independent variable which is corporate philanthropy. Three control variables are included in the equation TA representing total assets, Age and DR is debt ratio. $R O A_{i t-1}$ and $R O E_{i t-1}$ are the previous year performance, $C P * R O A_{i t-1}$ and $C P * R O E_{t-1}$ are interaction terms created to test moderator.

\section{Estimation Method}

The panel data for the current study consisted of textile companies observed for six years from 2009 till 2014 and the balanced panel was used as all the textile companies were observed in all the six years. In order to find the appropriate estimation method for the panel data the Hussmann test was 
performed. The insignificant value of Hussmann test lead to the acceptance of hypothesis that the random-effects model can be used in comparison to the fixed-effects model.

\section{Results}

Table 1 shows the estimation results for the dependent variable Return on Assets.

\begin{tabular}{lcccl}
\hline \hline Variable & \multicolumn{2}{l}{ Coefficient Std. Error } & t-Statistic & Prob. \\
\hline \hline C & -3.353201 & 9.534668 & -0.351685 & 0.7252 \\
TOTAL_ASSETS & 0.499333 & 0.661801 & 0.754507 & 0.4509 \\
AGE & -0.080798 & 0.047951 & -1.685021 & 0.0926 \\
DER & -0.004180 & 0.022465 & -0.186076 & 0.8525 \\
LN_CP & 0.561154 & 0.201437 & 2.785750 & 0.0056 \\
\hline \hline
\end{tabular}

Effects Specification

S.D. Rho

\begin{tabular}{lll}
\hline \hline Cross-section random & 5.804713 & 0.2557 \\
Idiosyncratic random & 9.904171 & 0.7443 \\
\hline \hline
\end{tabular}

Weighted Statistics

\begin{tabular}{llll}
\hline \hline R-squared & 0.028046 & Mean dependent var & 2.339195 \\
Adjusted R-squared & 0.019861 & S.D. dependent var & 10.02063 \\
S.E. of regression & 9.920623 & Sum squared resid & 46748.91 \\
F-statistic & 3.426576 & Durbin-Watson stat & 1.906378 \\
Prob(F-statistic) & 0.008915 & \\
& $=$
\end{tabular}

Table 1: Panel EGLS (Cross-section random effects model for ROA)

Table 2 shows the estimation results for the dependent variable Return on Equity.

\begin{tabular}{lcccc}
\hline \hline Variable & \multicolumn{2}{c}{ Coefficient Std. Error } & t-Statistic & Prob. \\
\hline \hline C & 26.84135 & 70.51437 & 0.380651 & 0.7036 \\
TOTAL_ASSETS & -1.513999 & 4.953391 & -0.305649 & 0.7600
\end{tabular}




$\begin{array}{lllll}\text { AGE } & -0.086138 & 0.342311 & -0.251636 & 0.8014 \\ \text { DER } & -1.344187 & 0.205694 & -6.534887 & 0.0000 \\ \text { LN_CP } & 0.754189 & 1.738190 & 0.433893 & 0.6646\end{array}$

Effects Specification

S.D. $\quad$ Rho

\begin{tabular}{lll}
\hline \hline Cross-section random & 33.03729 & 0.1110 \\
Idiosyncratic random & 93.50456 & 0.8890 \\
\hline \hline
\end{tabular}

Weighted Statistics

\begin{tabular}{llll}
\hline \hline R-squared & 0.082815 & Mean dependent var & -0.089382 \\
Adjusted R-squared & 0.075091 & S.D. dependent var & 97.45269 \\
S.E. of regression & 93.72239 & Sum squared resid & 4172346. \\
F-statistic & 10.72220 & Durbin-Watson stat & 1.734320 \\
Prob(F-statistic) & 0.000000 & & \\
& & & \\
\hline \hline
\end{tabular}

Table 2: Panel EGLS (Cross-section random effects model for ROE)

The results of table 1 show that the $R$ square value is .028 which show that independent variables cause $2.8 \%$ variance in dependent variable i.e. Return on Assets with $F=3.42 p<.05$. The results show that corporate philanthropy $(\beta=.56, p<.05)$ has significant positive effect on return on assets but the all three control variables are having insignificant relationship with ROA. The return on assets is a significant indicator of corporate financial performance so the result leading to the acceptance of hypothesis 1.

The results of table 2 show that the $R$ square value is.082 which show that independent variables cause $8.2 \%$ variance in dependent variable i.e. Return on Equity with $F=10.72 p<.05$. The results show that corporate philanthropy $(\beta=.56, p>.05)$ has insignificant effect on return on equity and the out of three control variables only debt to equity ratio has significant negative relationship with ROE.

Table 2 shows the estimation results for the dependent variable Return on Assets with moderator (previous year's financial performance) and interaction term.

\begin{tabular}{|c|c|c|c|}
\hline Variable & Coefficient Std. Error & t-Statistic & Prob. \\
\hline $\mathrm{C}$ & $-0.048460 \quad 5.777040$ & -0.008388 & 0.9933 \\
\hline
\end{tabular}


International Journal of Engineering and Management Sciences (IJEMS) Vol. 1. (2016). No. 1.

DOI: 10.21791/IJEMS.2016.1.47.

\begin{tabular}{|c|c|c|c|c|}
\hline TOTAL_ASSETS & 0.205743 & 0.411073 & 0.500501 & 0.6170 \\
\hline AGE & -0.047632 & 0.027679 & -1.720890 & 0.0859 \\
\hline DER & -0.011082 & 0.020758 & -0.533888 & 0.5937 \\
\hline LN_CP & 0.279488 & 0.168183 & 1.661812 & 0.0972 \\
\hline ROA_LAG1 & 0.197375 & 0.067261 & 2.934445 & 0.0035 \\
\hline \multirow[t]{3}{*}{ ROA_CP } & 0.024408 & 0.011835 & 2.062409 & 0.0397 \\
\hline & \multicolumn{4}{|c|}{ Effects Specification } \\
\hline & & & S.D. & Rho \\
\hline \multicolumn{3}{|l|}{ Cross-section random } & 0.000000 & 0.0000 \\
\hline \multicolumn{3}{|l|}{ Idiosyncratic random } & 9.867112 & 1.0000 \\
\hline & \multicolumn{4}{|c|}{ Weighted Statistics } \\
\hline R-squared & 0.135510 & \multicolumn{2}{|c|}{ Mean dependent var } & 4.092583 \\
\hline Adjusted R-squared & 0.124544 & \multicolumn{2}{|c|}{ S.D. dependent var } & 11.69512 \\
\hline S.E. of regression & 10.94263 & \multicolumn{2}{|c|}{ Sum squared resid } & 56637.61 \\
\hline F-statistic & 12.35719 & \multicolumn{2}{|c|}{ Durbin-Watson stat } & 2.119811 \\
\hline Prob(F-statistic) & 0.000000 & & & \\
\hline
\end{tabular}

Table 3: Panel EGLS (Cross-section random effects for ROA and interaction effect)

Table 4 shows the estimation results for the dependent variable Return on Equity with moderator and interaction term.

\begin{tabular}{lcccl}
\hline \hline Variable & \multicolumn{2}{l}{ Coefficient Std. Error } & t-Statistic & Prob. \\
\hline \hline C & 28.16024 & 54.89595 & 0.512975 & 0.6082 \\
TOTAL_ASSETS & -2.027143 & 3.901796 & -0.519541 & 0.6036 \\
AGE & -0.052582 & 0.259497 & -0.202628 & 0.8395 \\
DER & -1.211938 & 0.201205 & -6.023391 & 0.0000 \\
LN_CP & 1.473321 & 1.535255 & 0.959659 & 0.3377 \\
ROE_LAG1 & 0.210419 & 0.126861 & 1.658661 & 0.0978 \\
ROE_CP & 0.003447 & 0.017659 & 0.195204 & 0.8453
\end{tabular}




\begin{tabular}{|c|c|c|c|c|}
\hline & \multicolumn{4}{|c|}{ Effects Specification } \\
\hline & & & S.D. & Rho \\
\hline \multicolumn{3}{|l|}{ Cross-section random } & 0.000000 & 0.0000 \\
\hline \multicolumn{3}{|l|}{ Idiosyncratic random } & 93.69330 & 1.0000 \\
\hline & \multicolumn{4}{|c|}{ Weighted Statistics } \\
\hline & & & & - \\
\hline R-squared & 0.135879 & \multicolumn{2}{|c|}{ Mean dependent var } & 0.118208 \\
\hline Adjusted R-squared & 0.124918 & \multicolumn{2}{|c|}{ S.D. dependent var } & 103.8379 \\
\hline S.E. of regression & 97.13599 & \multicolumn{2}{|c|}{ Sum squared resid } & 4462944 \\
\hline F-statistic & 12.39621 & \multicolumn{2}{|c|}{ Durbin-Watson stat } & 1.944138 \\
\hline Prob(F-statistic) & 0.000000 & & & \\
\hline
\end{tabular}

Table 4: Panel EGLS (Cross-section random effects for ROE and interaction effect)

The results of table 3 show the results after the inclusion of moderator that is previous year's financial performance and interaction effect on return on assets. The $R$ square value is .135 which indicates that $13.5 \%$ variance in the Return on Assets (ROA) can be accounted for by the predictors with $F=12.35 p$ $<.05$. The results show that previous year's financial performance $(\beta=.19, p<.05)$ has significant positive relationship with ROA at the same time the coefficient of interaction term $(\beta=.02, p<.05)$ is also significant which shows that the previous year's financial performance moderate the relationship between corporate philanthropy and current corporate financial performance.

The results of table 4 show the results after the inclusion of moderator that is previous year's financial performance and interaction effect on return on equity. The $R$ square value is .138 which shows that independent variables cause $13.8 \%$ variance in Return on Equity with $F=12.39 p<.05$. The results show that previous year's financial performance $(\beta=.21, p>.05)$ has insignificant relationship with ROE at the same time the coefficient of interaction term $(\beta=.003, p>.05)$ is also insignificant relationship with ROE. So the pervious year's financial performance doesn't moderate the relationship between corporate philanthropy and current corporate financial performance.

\section{Discussion and conclusions}

In Pakistan, particularly large and blue chip companies with history of high profitability do spending under the head of corporate philanthropy. Results of this study support the findings of the previous literature that expenditure on corporate philanthropy significantly and positively affects ROA. Hence the spending on corporate philanthropy positively affects the corporate financial performance. However the insignificant relationship between corporate philanthropy with ROE which means the 
return to equity holders remain unaffected by spending on the corporate philanthropy due to the capacity and profitability of these companies to pay to the shareholders.

The pervious rears financial performance moderates the relationship between ROA and corporate philanthropy and this finding is consistent with the work of Waddock and Graves (1997). They argued that link between the financial performance and the corporate social performance is simultaneous i.e. past financial performance of the firm affect the corporate social performance which then effect the future financial performance of the firm. They argued that better financial performance of the firm lead to greater availability of slack resources enabling the firm to invest more in philanthropic programs and increase its social performance which in return enhances its financial performance.

\section{References}

[1] L. H. Amato, C. H. (2007), The effects of firm size and industry on corporate giving, Journal of Business Ethics 72.3:229-241.

[2] S. Brammer, A. Millington (2005), Corporate reputation and philanthropy: An empirical analysis, Journal of Business Ethics 61.1: 29-44.

[3] B. Carroll, Archie (1979), A three-dimensional conceptual model of corporate performance, Academy of management review 4.4, 497-505.

[4] B. Carroll, Archie (1991), The pyramid of corporate social responsibility: Toward the moral management of organizational stakeholders, Business horizons 34.4: 39-48.

[5] Choi, Jaepil, Heli Wang (2007), The promise of a managerial values approach to corporate philanthropy, Journal of Business Ethics 75.4: 345-359.

[6] L. Cochran, Philip (2007), The evolution of corporate social responsibility, Business Horizons 50.6: 449-454.

[7] Fombrun, Charles, Mark Shanley (1990), What's in a name? Reputation building and corporate strategy, Academy of management Journal 33.2: 233-258.

[8] Gao, Fox, Robert Faff, Farshid Navissi (2012), Corporate philanthropy: Insights from the 2008 Wenchuan earthquake in China, Pacific-Basin Finance Journal 20.3: 363-377.

[9] C. Godfrey, Paul (2005), The relationship between corporate philanthropy and shareholder wealth: A risk management perspective, Academy of management review 30.4: 777-798.

[10] Halme, Minna, Juha Laurila (2009), Philanthropy, integration or innovation? Exploring the financial and societal outcomes of different types of corporate responsibility, Journal of business ethics 84.3: 325-339.

[11] A. Hemphill, Thomas (1999), Corporate governance, strategic philanthropy, and public policy, Business Horizons 42.3: 57-62.

[12] Phillips, Rhonda (2000), Using Corporate Strategic Philanthropy for Economic Development, Economic Development Review 17.1: 7-11. 
[13] E. Porter, Michael, R. Mark Kramer (2002), The competitive advantage of corporate philanthropy, Harvard business review 80.12: 56-68.

[14] E. Post, James, A. Sandra Waddoc (1995), Strategic philanthropy and partnerships for economic progress, Contributions in Economics and Economic History: 65-86.

[15] E. Preston, Lee, P. Douglas O'bannon (1997), The corporate social-financial performance relationship, Business and society 36.4: 419.

[16] H. Saiia, David, B. Archie Carroll, K. Ann Buchholtz (2003), Philanthropy as strategy when corporate charity "begins at home", Business \& Society 42.2: 169-201.

[17] Seifert, Bruce, Sara A. Morris, and Barbara R. Bartkus (2004), Having, giving, and getting: Slack resources, corporate philanthropy, and firm financial performance, Business \& Society 43.2: 135-161.

[18] Vaidyanathan, Brandon (2008), Corporate giving: A literature review, Center for the Study of Religion and Society, University of Notre Dame

[19] A. Waddock, Sandra, B. Samuel Graves (1997), The corporate social performance-financial performance link, Strategic management journal 18.4: 303-319.

[20] Wang, Heli, Cuili Qian (2011), Corporate Philanthropy and Financial Performance: The Roles of Social Expectations and Political Access, Academy of Management Journal 54.6: 1159.

[21] Wang, Heli, Jaepil Choi, Jiatao Li (2008), Too little or too much? Untangling the relationship between corporate philanthropy and firm financial performance, Organization Science 19.1: 143-159. 